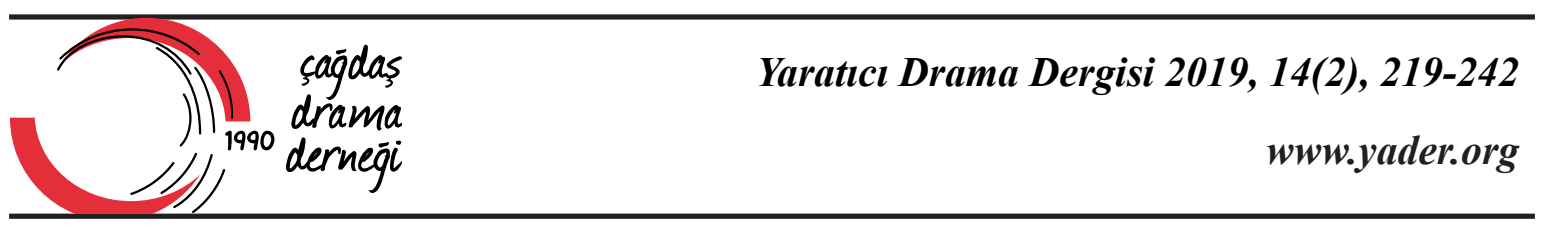

\title{
Sınıf Öğretmenliği Adaylarının Yaratıcı Drama Oturumu Planlama Sürecinde Yaşadıkları Sorunların İncelenmesi*
}

İhsan Metinnam ${ }^{1}$

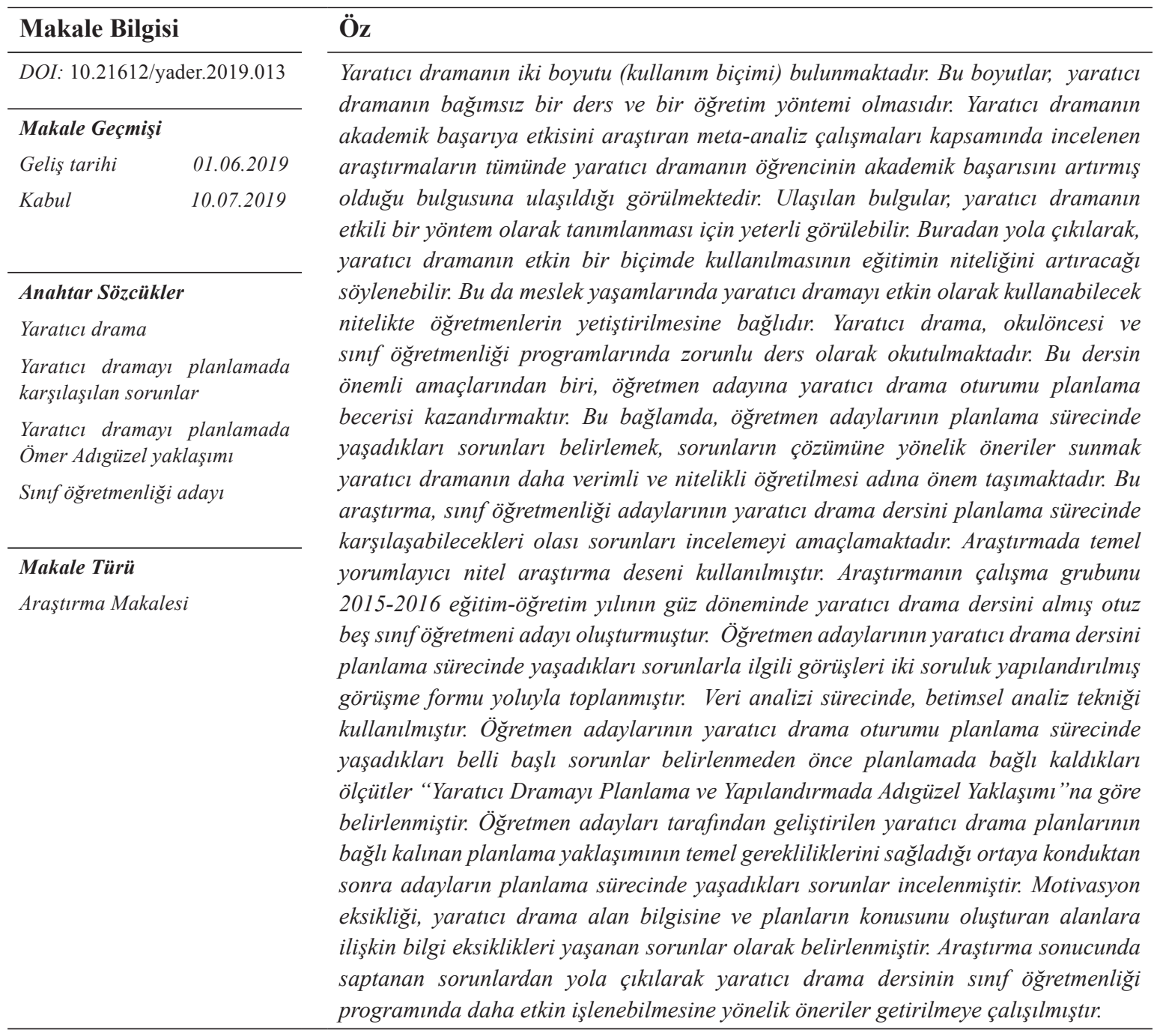

* $\quad$ Bu makale, 20-23 Nisan 2017 tarihleri arasında düzenlenmiş 26. Uluslararası Eğitim Bilimleri Kongresi’nde sunulmuş olan "Sınıf Öğretmeni Adaylarının Yaratıcı Drama Oturumu Planlama Süreçlerinde Karşılaștıkları Sorunların İncelenmesi” başlıklı sözlü bildiriden geliştirilerek oluşturulmuştur.

1 Dr., Ankara Üniversitesi Güzel Sanatlar Fakültesi, Ankara, Türkiye. E-posta: ihsanmetinnam@gmail.com. Orcid ID: https://orcid.org/0000-0001-6984-2693 


\section{Investigation of the Problems of Primary School Teacher Candidates in the Planning Process of Creative Drama Session**}

\begin{tabular}{lr}
\hline Article Info \\
\hline DOI: $10.21612 /$ yader.2019.013 \\
\hline Article History & \\
Received & 01.06 .2019 \\
Accepted & 10.07 .2019 \\
&
\end{tabular}

Keywords

Creative drama

Problems in planning creative drama

Ömer Adigüzelss approach to planning creative drama

Primary school teacher candidate

\section{Article Type}

Research paper

\begin{abstract}
Creative drama has two dimensions (usage forms). These dimensions are that creative drama is an independent lesson and a teaching method. In all of the meta-analysis studies investigating the effect of creative drama on academic achievement, it was seen that creative drama increased the academic achievement of students. The findings can be considered sufficient to define creative drama as an effective method. From this point of view, it can be said that the effective use of creative drama will increase the quality of education. This depends on the training of teachers who can use creative drama effectively in their professional lives. Creative drama is taught as a compulsory course in the primary school teacher program as well as preschool teacher programs. One of the main objectives of this course is to provide the student with the ability of planning creative drama sessions. In this context, it is important to identify the problems that teacher candidates have experienced during the planning process and to offer suggestions for the solution of the problems in order to teach creative drama more efficiently. This research aims to examine the potential problems that teacher candidates may encounter during the planning process of creative drama lesson. In the study, basic interpretive qualitative research design was used. The study group of the research consisted of thirty-five teacher candidates who took creative drama course in the fall semester of 2015-2016 academic year. Teacher candidates'opinions about the problems they experienced during the planning process of creative drama course were collected through a structured interview form with two questions. In the data analysis process, descriptive analysis technique was used. Before determining the major problems experienced by the teacher candidates during the creative drama session planning process, the criteria that they adhered to in planning were determined according to "Adigüzel Approach in Planning and Structuring Creative Drama". After it was revealed that creative drama plans developed by teacher candidates provided the basic requirements of the planning approach, the problems experienced by teacher candidates in the planning process were examined. Lack of motivation, lack of knowledge of creative drama and knowledge of the subject areas of the plans were identified as problems. Based on the problems identified as a result of the research, suggestions were made to make creative drama lesson more efficiently.
\end{abstract}

** This paper was developed from the oral-presentation titled as "Examining the Problems of Primary School Teacher Candidates in the Planning Process of Creative Drama Session" and was presented at the 26th International Congress of Educational Sciences between April 20-23, 2017. 


\section{Giriş}

Yaratıcı dramanın iki boyutu (kullanım biçimi) bulunmaktadır. Bu boyutlar, disiplin olarak yaratıcı drama ve yöntem olarak yaratıcı dramadır. Farklı kaynaklarda yaratıcı dramanın boyutlarının ders-yöntem, amaç-araç olarak yaratıcı drama biçiminde de geçtiği bilinmektedir. Disiplin olarak yaratıcı drama; matematik, fizik, Türkçe derslerinde olduğu gibi yaratıcı dramanın kendi alan bilgisinin ele alındığı süreçler olarak tanımlanabilir. Yöntem boyutu ise şu şekilde tanımlanabilir: "Yaratıcı drama sahip olduğu teknikleri işte koşarak drama alanının kendi konuları dışındaki konuları ögretmede kullanılır. Bu konular amaçları uygun olan her ders ya da her eğitim konusu için geçerli bir durumdur. Bu yöntemde işlenecek bir konunun dramatik bir çatışma içerisinde canlandırmalarla bizzat yaşatılarak öğretilmesi söz konusudur” (Adıgüzel, 2018).

Yaratıcı drama, iki boyuta ayrılmış gibi gözükse de yaratıcı dramanın hem ders boyutu hem yöntem boyutu bütün uygulamalarda işe koşulur. Yaratıcı drama alanında gerçekleştirilmiş çalışmaların bazılarında yöntem boyutuyla alan bilgisinin ayrı tutulduğu bir anlayışın göze çarptığı söylenebilir. Bu çalışmalar, temel kavramlara, tekniklere, yaratıcı dramanın alan bilgisine ilişkin basit hatalarla doludur. Sözgelimi, yapılan bilimsel çalışmaların çoğunluğunda yaratıcı drama halen bir teknik olarak ele alınmaktadır. Oysa yaratıcı drama, rol oynama, doğaçlama, donuk imge gibi kendine özgü tekniklere sahip bir disiplin ve yöntemdir. Bir diğer sık yapılan hata ise tekniklerin adlandırılmasında yaşanmaktadır. Sözgelimi, canlandırma ya da oyun birer teknik olarak plan künyesine yazılabilmektedir. Oysa canlandırma, yaratıcı dramanın içerisinde mutlaka yer alması gereken bir eylem olduğu gibi aynı zamanda planlama aşamalarından biridir. Bir diğer hata ise yaratıcı dramanın yöntem olarak kullanıldığı çalışmalarda ortaya çıkmaktadır. Belirlenen konu ile ilgili yapılandırılan yaratıcı drama oturumlarının birçoğunda didaktik ve mekanik bir şablonculuk göze çarpmaktadır. Sözgelimi, geri dönüşüm konusunun yaratıcı dramayla öğretildiği bir sürecin ısınma hazırlık aşamasında karton bardaklarla bir ritim çalışması yaptırıldıktan sonra canlandırma aşamasında dramatik yapısı sağlam olmayan doğaçlamadan çok küçük rol oyunları olarak tanımlanabilecek etkinliklerle devam edilmektedir. Oysaki bir yaratıcı drama oturumu planlanırken odaktaki baştan sonra dramatik bir kurgu içerisinde ele alınmalıdır. Katılımcılar daha sürecin en başından kurguya girmelidir. Böylece tıpk1 iyi bir roman okunurken kurgunun içerisine girilmesi gibi katılımcılar da inanarak yapılandırılan sürecin içine girerler. Katılımcı rolüne inandıktan sonra daha fazla sorumluluk almaya gönüllü olur. Böylece rol ve kurgu içerisinde tüm süreci derinlemesine sorgulamaya hazır bir hale gelebilir. Bu duruma, "inançsızlı̆̆ın geçici ve bilinçli olarak askıya alınması" denir. Yaratıcı drama süreçleri -mış gibi yapmaya yani kurgusallığa dayalıdır. Kurgu, kendi içerisinde tutarlı bir kurmaca gerçekliğe dönüşmedikçe, katılımcıların -mış gibi olana yani gerçek olmayan ilişkin inançsızlık durumları devam edecektir. Bunu engellemek için yaratıcı dramanın eğitsel ve estetik boyutu eş zamanlı yapılandırılmalıdır.

$\mathrm{Bu}$ hataların çoğunluğunun yaratıcı dramanın iki boyutunu birbirinden çok ayrı şeylermiş gibi düşünmekten kaynaklandığı ifade edilebilir. Oysa yaratıcı dramanın yöntem ve alan bilgisi, eğitsel ve estetik süreçleri birbirine sıkı sıkıya bağlı iki sarmal gibidir.

Yaratıcı dramayı yöntem olarak kullanmak isteyen bir öğretmen öncelikle kendisini yaratıcı drama alanında yetiştirmelidir. Bunun yanında, yaratıcı dramanın yöntem olarak kullanılmasının alan bilgisinden ayrı düşünülmemesi gerektiğinin farkında olmalıdır. Alan bilgisinden yoksun bir yaratıcı drama uygulaması teknik bir şablonculuğa indirgenmiş basit bir oyun ya da taklit etkinliğine 
dönüşebilir. Bowell ve Heep'in (2001, s.5) “Drama Öğrenim Sarmalı”nda da yaratıcı dramanın² ders ve yöntem boyutunun ayrılmaz bir bütün olduğu gösterilmektedir:

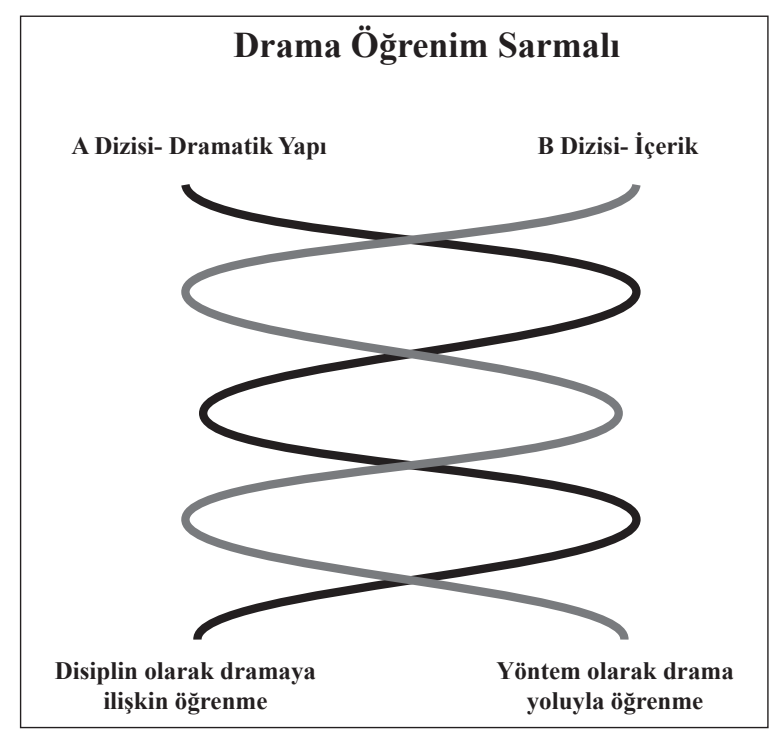

Şekil 1. Bowell ve Heep'in "Drama Öğrenim Sarmalı"

Bowell ve Heep'e (2001, s. 4) göre; "Ĕğer amaç yaratıcı dramanın alan bilgisiyle ilgili becerileri arttırmaktaysa 'A Dizisi'daha ön plana çıkacaktır. Ancak, eş zamanlı olarak 'B Dizisi'nin de işe koşulması gerekmektedir. Çünkü yapılan çalışma mutlaka bir 'içeriğe'sahip olmak zorundadır. Aynı biçimde eğer, yaratıcı drama yoluyla başka bir içerik öğretiliyorsa, 'B Dizisi' daha ön plana çıkacaktır. Ancak, 'A Dizisi'nin sürece eklemlenmesi gerekir ki yapılan şey yaratıcı drama olsun. Çünkü içeriği aktarmak için yaratıcı drama tekniklerine, dramatik yapı içerisinde sunulmuş canlandırmalara gereksinim bulunmaktadır". Yaratıcı dramanın kendi konusu dışındaki konular öğretilirken de konunun dramatik bir çatışma yani dramatik bir yapı içerisinde, yaratıcı dramanın tekniklerini işe koşarak canlandırmalarla öğretilmesi söz konusudur.

Kısacası yaratıcı dramayı yöntem olarak kullanmak isteyen bir öğretmenin hem kendi öğretmenlik alanının bilgisine hem de yaratıcı dramanın alan bilgisine hakim olması gerekmektedir.

Adıgüzel'e (2018) göre lider/öğretmen/eğitmenin sahip olması gereken özellikler şu şekildedir: "Yaratıcı drama alanında süreci tasarlayan, biçimlendiren, yöneten lider/eğitmenöğretmen kavramından; yaratıcı drama süreçlerine hakim, kuramsal ve uygulamalı çalışmalarda yeterli, uygulama becerisi de olan ya da aynı süreçleri bilip, farklı bir alanda uzman olan, yaratıcı dramayı bir yöntem olarak kendi alanında kullanan ögretmen anlaşılmalıdır." Mesleki Yeterlik Kurumu, Resmi Gazete'de 09.06.2018-30446 tarih ve sayı ile çıkan karar ve 18UMS0674-6 referans kodu ile yaratıcı drama eğitmenliğini “6.Seviye Yaratıcı Drama Eğitmeni” başlığıyla bir meslek dalı olarak tanımlamıştır. Bu kararın ardından, yaratıcı drama eğitmenliği ilgili belirlenen ölçütlerden (Mesleki Yeterlilik Kurumu, 2018) de yola çıkılarak bir yaratıcı drama eğitmeninin sahip olması gereken yeterlik ve tutumları kazanmak için yapması gerekenler aşağıdaki başlıklarda özetlenebilir:

2 Ulusal ve uluslararası alanyazında; "drama, eğitimde drama, yaratıcı drama, eğitimde yaratıcı drama" gibi kullanımları olan bu kavram bu çalışmada "yaratıcı drama" olarak kullanılmıştır. 
1. Yaratıcı drama eğitimi almak (demokratik kitle örgütlerinin verdiği liderlik/eğitmenlik programlarına, üniversitelerde yürütülen lisansüstü programlara başvurmak),

2. Yaratıcı dramanın alan bilgisine (özellikle tiyatro ve eğitim konusunda olmakla birlikte sanat, sosyoloji, psikoloji, felsefe vd.) sahip olmak,

3. Yaratıcı drama uygulamalarıyla ilgili güncel gelişmeleri takip etmek (kongre, seminer ve atölyelere katılmak, alanla ilgili süreli yayınları takip etmek),

4. Yaratıcı drama uygulama becerisine sahip olmak (yapılandırma, tasarlama, planlama, değerlendirme), uygulama ile ilgili deneyimlerini arttırmak, yaptı̆̆ 1 uygulamalara eleştirel bir gözle bakmayı öğrenmek,

5. Yaratıcı dramanın (demokratik kültür, estetik bakış açısı ve yaratıcılık, geliştirme, bütün katılımcılara eşit mesafede olma, kalıplara sahip olmadan düşünme) gerektirdiği temel nitelikler konusunda kendi tutumlarını geliştirmek.

Türkiye'de yaratıcı drama araştırmalarının büyük çoğunluğunu yöntem boyutuna odaklanan çalışmalar oluşturmaktadır. Türkiye'de 1985-2012 yılları arasında yaratıcı alanında yapılmış 1144 çalışmanın \% 72,7'si yaratıcı dramanın yöntem boyutuyla ilgilidir (Adıgüzel, 2016, s. 11). Bunun içine, yaratıcı dramanın hem yöntem hem ders boyutunu ele alan çalışmalar da katılırsa oran \% 77'ye çıkmaktadır (Adıgüzel, 2016, s. 11). Bunun yanında, yaratıcı dramanın akademik başarıya, dersler karşı tutumlara, beceri geliştirmeye etkisini inceleyen birçok meta-analiz araştırmasında da yaratıcı dramanın etkili bir yöntem olduğu ortaya konmuştur.

Yaratıcı dramanın akademik başarıya etkisini ele alan meta-analiz araştırmalarında, drama temelli öğretimin eğitsel ortamlardaki başarı üzerinde pozitif ve kayda değer bir etkisinin olduğu (Patall ve Cawthon ve Steingut, 2014), yaratıcı dramanın öğrencinin akademik başarısını artırmış olduğu (Ulubey ve Toraman, 2015), yaratıcı dramanın akademik başarı üzerinde kayda değer bir etkisinin bulunduğu (Batdı ve Batdı, 2015), derslerde yaratıcı drama kullanımının akademik başarıyı etkileme düzeyinin yüksek olduğu (Akdemir ve Karakuş, 2016) sonuçlarına ulaşıldığı görülmektedir.

Ek olarak, yaratıcı dramanın genel anlamda akademik başarıya etkisini ele alan meta-analiz çalışmalarının yanında, belli bir disiplindeki akademik başarıya etkisini alan meta-analiz araştırmaları da bulunmaktadır.

Çelik (2013), ilköğretim matematik derslerinde kullanılan alternatif öğretim yöntemlerinin akademik başarıya etkisini araştırdığı meta-analiz araştırmasında ilköğretim matematik derslerinde kullanılan alternatif öğretim yöntemlerinin, akademik başarı açısından öğretmen merkezli öğretim yöntemine göre daha etkili olduğunu ortaya koymuştur. Araştırmacının alternatif yöntemler içerisinde değerlendirdiği yöntemlerden bir tanesi de yaratıcı dramadır.

Cantürk-Günhan'ın (2016) Türkiye'de uygulanan drama temelli eğitimin matematik başarısına etkisini araştırdığı meta-analiz araştırmasının sonuçlarına göre; yaratıcı drama yönteminin matematik başarısının artırılmasında oldukça etkili bir yöntem olduğu ortaya çıkmıştır. Ayrıca aynı araştırmanın bir diğer sonucuna göre; yaratıcı drama temelli eğitimin öğrencilerin öğrenim kademesine göre incelendiğinde akademik başarılarda en yüksek etki büyüklüğünün okul öncesi ve birinci kademede olduğu saptanmıştır.

Yaratıcı dramanın akademik başarıya etkisini ele alan meta-analiz araştırmalarına ek olarak, bir de yaratıcı dramanın derslere karşı tutum, öğrenci becerilerinin geliştirilmesi üzerindeki etkisinin 
ne olduğunu ele alan meta-analiz araştırmaları bulunmaktadır. Toraman ve Ulubey (2016), yaratıcı dramanın derse yönelik tutum üzerindeki etkisini ele aldıkları meta-analiz araştırmasında yaratıcı dramanın derslere yönelik tutumu olumlu yönde etkilediği sonucuna ulaşmıştır. Ulubey'in (2018), bir yöntem olarak yaratıcı dramanın beceri geliştirmeye etkisini incelediği meta-analiz araştırmasında yaratıcı dramanın beceri geliştirmede etkili olduğu sonucuna varılmış, ancak bu durumun okul öncesi, lise ve yükseköğretim düzeyinde sınırlı kaldığı da ayrıca belirtilmiştir. Uygulandığı her alanda başarıyı artırması yaratıcı dramanın etkili bir yöntem olarak tanımlanması için yeterli sayılabilir. $\mathrm{Bu}$ bağlamda, sözü edilen araştırmalarda ele alınan uygulamalar bir eğitmen tarafından gerçekleştirildiği için uygulamaları gerçekleştiren eğitmenlerin de belli bir yetkinlik düzeyinde olduğu sonucuna varılabilir.

Yaratıcı dramayla ilgili çalışmaların bu denli etkili olduğuna ilişkin yapılan araştırmaların aksine alanyazında yaratıcı drama dersinin planlanmasına yönelik yeterlilikle ilgili yapılan çalışmalarda öğretmenlerin ve öğretmen adaylarının kendilerini bu konuda yetersiz, orta yeterlikte veya ara sıra yeterli gördükleri sonucuna ulaşan araştırmalar göze çarpmaktadır. Çetingöz ve CantürkGünhan (2011), okulöncesi öğretmen adaylarının yaratıcı drama süreçlerini planlama becerilerinin geliştirilmesine dönük yaptıkları araştırmanın uygulama süreci öncesinde okulöncesi öğretmen adaylarının yaratıcı drama dersini planlama konusunda bilgi eksikliğine sahip olduklarını saptamıştır.

Akyel ve Çalışkan (2013), okulöncesi eğitim kurumlarında görev yapan öğretmenlerin drama yöntemi yeterliliklerinin değerlendirilmesine ilişkin çalışmalarında, öğretmenlerin drama süreçlerini planlamada kendilerini ara sıra yeterli bulduklarını ortaya koymuşlardır. Elitok-Kesici (2014), sınıf öğretmenlerinin drama dersini nasıl işledikleri ve bu dersi işlerken karşılaştıkları güçlükler ve eksikliklerin neler olduğunu ortaya koyma amacıyla gerçekleştirdiği araştırmasında öğretmenlerin drama dersini işlerken kendilerini yetersiz hissettiklerini belirtmektedir. Çelikkaya ve Koç’un (2015), öğretmenlerin sosyal bilgiler dersinde drama yöntemi uygulama yeterlilikleri üzerine yaptıkları araştırmanın sonucunda elde edilen verilerde en düşük ortalama "Drama yöntemine uygun ders planı yaparım.” ifadesine ait çıkmıştır. Şahin'in (2017) yaratıcı drama dersini almış ve almamış olan sınıf öğretmeni adaylarının öz-yeterliliklerini karşılaştırdığı çalışmasında da adayların yaratıcı dramayı yöntem olarak kullanma konusundaki yeterlilikleri orta düzeyde çıkmıştır.

Özer, İlhan ve Taşkaya (2018) tarafından sınıf öğretmenlerinin drama yöntemine ilişkin görüşlerinin incelendiği araştırma kapsamında görüşme yapılan öğretmenlerin \%60’ının kendilerini uygulama konusunda ya yetersiz ya da orta yeterlilikte gördükleri ortaya çıkmıştır. Şahin (2018)'in sınıf öğretmenliği ve Türkçe öğretmenliği adaylarıyla yaptığı bir başka çalışmada ise öğretmen adaylarının yaratıcı drama konusundaki öz-yeterlilikleri orta düzeyde çıkmıştır. Kuşdemir-Kayıran (2018), öğretmen adaylarının yaratıcı drama yöntemini kullanmaya dönük öz-yeterlik algılarını ve yaratıcı dramaya ilişkin tutumlarını geliştirerek, dramayı planlayabilme ve uygulayabilme süreçlerine katkı yapmak amacıyla gerçekleştirdiği araştırma için yaptığı ön görüşmede öğretmen adaylarının en çok yaratıcı drama dersini planlama konusunda sıkıntı yaşadıkları bulgusuna ulaşmıştır.

Yaratıcı drama çalışmalarının büyük çoğunluğunun yöntem boyutuna odaklanıyor olması yaratıcı drama eğitmeninin niteliğinin ve yeterliklerinin takip edilmesini bir kat daha önemli kılmaktadır. Okulöncesinden yükseköğretime kadar geniş bir yelpazede yöntem olarak kullanılan yaratıcı dramanın, alanyazındaki ilgili çalışmalar doğrultusunda, öğretmenlerin ve öğretmen adaylarının planlama ve uygulama becerilerinin geliştirilmesi, bu konuyla ilgili sorunların ortaya 
konması da var olan uygulamaların niteliğinin artırılması açısından öncelikli olarak ele alınması gereken bir konu olarak öne çıkmaktadır. Bu çalışmanın problemini yaratıcı dramayı ilkokul düzeyinde bir yöntem olarak kullanacakları öngörülen sınıf öğretmenliği adaylarının yaratıcı drama dersini planlamada sorunlarla karşılaşıp karşılaşmadıklarını ortaya koymak oluşturmaktadır. Alanyazında da belirtildiği üzere öğretmen ve öğretmen adaylarının yaratıcı drama ile ilgili kendilerini en yetersiz gördükleri konu planlama ve uygulama becerileridir. Buradan yola çıkarak, çalışmanın amacının, öğretmenlik eğitimi alan adayların yaratıcı dramayı planlama süreçlerinde karşılaştıkları sorunları belirlemek ve incelemek olarak gösterilebilir.

$\mathrm{Bu}$ sorunların belirlenmesinin öğretmen adaylarının ilerideki uygulamalarının yetkinlik düzeyine katkı yapabileceği var sayılmıştır. Çalışmanın amacı doğrultusunda aşağıdaki soruya yanıt aranmıştır:

Sınıf öğretmenliği adaylarının yaratıcı drama oturumları planlarken karşılaştıkları sorunlar nelerdir?

\section{Yöntem}

\section{Araștırma Modeli}

$\mathrm{Bu}$ çalışmada temel yorumlayıcı nitel araştırma deseni kullanılmıştır. Merriam (2002) sekiz farklı nitel araştırma deseni tanımlamıştır. Bu desenlerden biri “temel yorumlayıcı nitel araştırma"dır. Merriam (2002), temel yorumlayıcı deseni "genel amacı insanların yaşamlarını ve deneyimlerini nasıl anlamlandırdıklarını anlamak" olan bir çalışma olarak tanımlar. Bu amaç tüm nitel araştırmaların temelini oluştururken, Merriam, diğer stratejilere dayanan çalışmaların temel yorumlayıcı çalışmalarda bulunmayan ek amaçlara da sahip olduğunu belirtir (sözgelimi, gömülü teoride teori geliştirmek, fenomenolojideki bir olgunun özünü tanımlamak, vd.). Merriam için temel çalışmalar, diğer stratejilerin kendilerine özgü özelliklerini paylaşmayan çalışmalardır. Temel yorumlayıcı nitel araştırmanın kendinde özgü doğasını anlaşılır kılmak adına Batılı olmayan bir kültürde yetişkin öğrenmesini inceleyen bir çalışmadan örnek vermektedir. Bu çalışmada kültür, verileri yorumlarken önemli bir kaynak olmasına karşın, örnek verdiği çalışma etnografi deseniyle yapılmış bir çalışma değildir. Çünkü çalışmanın etnografi deseninde olabilmesi için araştırmacının o toplulukla uzun süre kalması veya katılımcı bir gözlemci olarak sürece dahil olması gerekirdi. Bu çalışmada, yalnızca yetişkin öğrenmesinin nasıl gerçekleştiğine odaklanılmıştır. Kültürü tanımlamak başat amaç değildir. Çalışmanın asıl amac1, o kültürdeki yetişkinlerin öğrenme sürecini anlamaktır. Temel yorumlayıcı nitel araştırma (basic interpretive qualitative study), araştırmacının katılımcıların bir anlamı ya da fenomeni nasıl oluşturduğunu anlamaya çalışmasıyla ilgilendiğinde kullanılabilir. Temel yorumlayıcı nitel araştırma; görüşmelerden, gözlemlerden, doküman analizinden (katılımcıların yazılı süreç çıktıları gibi) yararlanan tümevarımsal bir araştırma stratejisidir (Merriam, 2002). Bu bağlamda, temel yorumlayıcı nitel araştırma yorumlayıcı paradigmaya uygun olan ancak birtakım ek amaçların yerine getirilmesine gereksinim duyulmayan nitel araştırmalar için kullanılan bir desendir.

$\mathrm{Bu}$ çalışma, yalnızca sınıf öğretmenliği adaylarının yaratıcı dramada planlama yaparken karşılaştıkları sorunları belirleyip inceleyerek anlamaya odaklanmaktadır. Bu bağlamda, çalışma 2015-2016 eğitim-öğretim yılının güz döneminde sınıf öğretmenliği programında zorunlu 
dersler arasında bulunan "Drama” dersi kapsamında gerçekleştirilmiştir. Dersin izlencesi gereği temel yaratıcı drama çalışmaları gerçekleştirildikten sonra temel kavramlar ve temel tekniklerin öğretilmesine geçilmiştir. Bunun ardından ise yaratıcı dramada planlama uygulamalı ve kuramsal olarak aktarılmıştır. Dersin son haftalarında ise öğretmen adayları belirledikleri konu ve kazanımlar odağında yaratıcı drama planları geliştirerek, bu planları sınıf arkadaşlarına uygulamışlardır. $\mathrm{Bu}$ süreçte, dersin öğretim elemanından da yardım almışlardır. Öğretmen adayları, yaratıcı drama ders planlarını geliştirirlerken eş zamanlı olarak dersin öğretim elemanı tarafından hazırlanmış görüşme formlarını da doldurmuşlardır. Öğretmen adaylarının görüşme formlarını ders planlarını geliştirirken doldurmalarındaki amaç yaşadıkları sorunları anlık olarak not düşmelerini sağlamaktır. Dersin sonunda tüm ders planı örnekleri değerlendirme için alınırken görüşme formları da beraberinde toplanmıştır. Bu sürecin ardından, görüşme formları ve planlar beraber değerlendirilerek öğretmen adaylarının planlamada ne gibi sorunlarla karşılaştıkları ortaya konmaya çalışılmıştır. Bu bağlamda, çalışma sürecinde temel yorumlayıcı nitel araştırmaya uygun olarak görüşme ve doküman analizinden yararlanılmış olup, öğretmen adaylarının yaratıcı drama planlama sürecinde yaşadıkları sorunları nasıl anlamlandırdıkları ortaya çıkartılmaya çalışılmıştır.

\section{Çalışma Grubu}

Araştırmanın çalışma grubunu 2015-2106 eğitim-öğretim yılı güz döneminde bir devlet üniversitesinin eğitim bilimleri fakültesinde öğrenim görmekte olan ve beşinci yarıyıllarında "Drama" dersi almakta olan otuz beş sınıf öğretmenliği üçüncü sınıf öğrencisi oluşturmuş̧tur. Çalışma grubunun öğretmen adaylarından oluşmasının nedeni, öğretmen adaylarının yaratıcı dramayı ileriki yıllarda öğretmenlik mesleğini icra ederlerken derslerinde bir yöntem olarak kullanacak olmalarıdır.

\section{Veri Toplama Araçları}

Çalışmanın ana veri toplama aracı olarak yapılandırılmış görüşme formu kullanılmıştır. Yapılandırılmış görüşme formu yaratıcı drama sürecini planlarken bağlı kalınan ölçütler ve planlamada karşılaşılan sorunları ele alan kapalı uçlu iki sorudan oluşturulmuştur. Görüşme formu oluşturulurken iki yaratıcı drama alan uzmanından ve dilsel denetim için de bir Türk dili uzmanından görüş alınmıştır. Alınan görüşler doğrultusunda gerçekleştirilen düzeltmelerin ardından görüşme formuna son biçimi verilmiştir. Yapılandırılmış görüşme formunda yer alan iki soru aşağıdaki gibidir:

1. Atölye içeriğini geliştirirken herhangi bir zorluk yaşadım mı? Eğer bir zorlukla karşılaştıysam, bunlar nelerdi (ekonomik sıkıntılar, alana ilişkin bilgi yetersizliği, motivasyon eksikliği vd.)?

2. Atölyenin içeriğini geliştirirken oyun seçiminde, dramatik durum yazarken, araç-gereç belirlerken, varsa eğer önceden yazılmış bir metni, hareketli ya da hareketli olmayan bir görseli (fotoğraf, resim, video vd.) seçerken herhangi bir ölçüte bağlı kaldım mı? Kaldıysam bunlar nelerdi (kazanımla ilişkisi, eğitim etiği, işlevselliği vd.) ?

Yapılandırılmış görüşme formuna ek olarak, öğretmen adayları tarafından hazırlanmış olan yaratıcı drama ders planları da doküman türünde veri toplama araçları olarak değerlendirilmiştir. Bu planlardan öğretmen adayları tarafından görüşme formuna verilen yanıtların yorumlanmasında yararlanılmıştır. 


\section{Verilerin Toplanması}

Çalışmanın verileri görüşme ve doküman analizi yoluyla toplanmıştır. Görüşme yoluyla toplanan veriler için oluşturulmuş olan yapılandırılmış görüşme formu dönemin başında öğretmen adaylarına ulaştırılmıştır. Öğretmen adayları, dersin kapsamında yaratıcı drama ders planı hazırlamakla yükümlü tutulmuşlardır. Öğretmen adayları görüşme formunu kendi planlarını hazırlarlarken doldurmuşlardır. Böylece öğretmen adaylarının yaratıcı drama ders planlarını geliştirirlerken karşılaştıkları sorunları anlık olarak not etmeleri amaçlanmıştır. Doküman analizi yoluyla toplanan verileri öğretmen adaylarının yaratıcı drama ders planları oluşturmuştur.

\section{Verilerin Analizi}

Çalışmanın verileri betimsel analiz tekniği kullanılarak çözümlenmiştir. Betimsel analizde, elde edilen veriler, daha önceden belirlenen temalara göre özetlenir ve yorumlanır (Yıldırım ve Şimşek, 2013). Öğretmen adaylarından görüşmeler yoluyla toplanan veriler, öğretmen adaylarının yaratıcı drama planlama sürecinde karşılaştıkları sorunlara ilişkin görüşlerini ortaya koyacak biçimde çözümlenmiştir. Buna göre görüşme sonunda elde edilen verilerin deşifresinden sonra, veriler satır satır kodlanmış, ortak kodlar ortak kategoriler altında birleştirilmiş, son olarak da ortak kategoriler önceden belirlenmiş temalarla ilişkilendirilmiştir. Gerekli yerlerde öğretmen görüşlerinden doğrudan alıntılar verilerek yorumlanmıştır. Bunun yanında, çalışmanın sağlamlığını artırmak için bir başka uzmana da veriler kodlatılmıştır. Kodlama yapan uzmanla, araştırmacının kodları karşılaştırılarak aralarında tutarlılık sağlanmaya çalışılmıştır.

Planlama sürecinde neyin sorun olduğu belli bir yaratıcı drama planlama yaklaşımının ilkelerine bağlı kalınarak tanımlanmıştır. Bu planlama yaklaşımı, öğretmen adaylarının da kendi planlarını geliştirirken bağlı kaldıkları yaklaşımdır. Türkiye'de yaratıcı drama dersini veya yöntemini planlamada yaygın olarak kullanılan aşamalılık sistemi ve yapılandırma yaklaşımı Ömer Adıgüzel'e aittir. Bu yaklaşım, araştırmacı tarafından "Yaratıcı Dramayı Planlama ve Yapılandırmada Adıgüzel Yaklaşımı” olarak adlandırılmıştır. Ömer Adıgüzel, Türkiye'de yaratıcı drama alanında gerçekleştirilen birçok akademik çalışmada kullanılan bu yaklaşımı ilk olarak 2002 yılında KKTC'de düzenlenmiş olan "11. Eğitim Bilimleri Kongresi”nde sunduğu "Eğitim Bilimlerinde ve Sanat Eğitiminde Yöntem, Disiplin ve Sanatsal Boyutlarıyla Yaratıcı Drama” başlıklı bildirisiyle açıklamış; 2006 yılında "Yaratıcı Drama Dergisi”nin ilk sayısındaki "Yaratıcı Drama Kavramı, Bileşenleri ve Aşamaları" başlıklı makalesinde geliştirdiği planlama yaklaşımına ilişkin daha ayrıntılı bilgiler aktarmıştır. Adıgüzel'in yaklaşımının geçerliliği dünyadaki farklı yaratıcı drama planlama yaklaşımlarına bakılarak da anlaşılabilir.

Dünyada yaratıcı drama süreçlerinin planlanma ve yapılandırılma süreçleri, küçük ayrıntılar dışında birbiriyle tutarlılık göstermektedir. Yaratıcı drama alanının ilk öncülerinden Winfred Ward'un planlama yaklaşımı alanda uzun yıllar etkili olan bir planlama yaklaşımıdır. Ward, ders planlama konusunda doğrusal/çizgisel bir yaklaşım benimsemiş ve çocukların sıklıkla karşılaşabileceği dizi etkinliği belli bir sırayla sunmayı önermiştir: "Sözü edilen dizi duyu-algı/yoğunlaşma etkinlikleriyle başlayıp devinim/pantomim, diyalog, karakterize etme ve doğaçlama/ öykü canlandırmayla devam eder" (Wright, 1985 'ten akt; Taylor, 2003). Ward'un belli bir sırayı izleme mantığı, belli bir aşamalılığın da göstergesi olarak algılanabilir. Kase-Polisini'nin (1989'dan akt; Taylor 2003) anlayışı da Ward ile benzerlik göstermektedir: "Plan, önceden açıkça belirlenmiş hedefleri, 1sınma etkinliği, kullanılacak kaynak materyalleri, aynı hedefleri gerçekleştirmeye yarayacak alternatif kaynak materyalleri, uygulanacak teknikleri ve rahatlama etkinliği içermelidir”. 
Fleming (2003) kendi yaklaşımındaki plan künyesinde, kazanımlara, içeriğin odağının ne olduğuna ve süreçte kullanılacak araç-gereçlere; yaratıcı drama süreci aşamaları olarak "1sınmaoyunları/ikili doğaçlamalar/grup tartışması/çalışmaların gönüllü sunulması/değerlendirme" başlıklarına yer vermiştir. Toyle ve Prendville (2000) ise kendi yaklaşımlarının plan künyesinde, araç-gereçler ve uyaranların, açıkça belirtilmiş öğrenme kazanımlarının önemine dikkat çekmiş; ancak yaratıcı drama sürecinin planlanmasına dönük tam bir aşamalılık ortaya koymamıştır. Bunun yerine, dramatik kurgunun bileşenleriyle- yaratıcı drama sürecinde yapılması gerekenleri karıştırdığ1 bir "olması gerekenler" listesi hazırlamıştır: "Bağlamlar-zamanı ve mekanı sınırlandırma/Roller (hem öğretmen hem öğrenci)/Odak/Anahtar Anlar”.

Toyle ve Prendville'nin dramatik yapıya ve yaratıcı dramanın canlandırmalarla ilerleyen özelliğine dikkat çektiği ifade edilebilir. McCaslin (2016) de kitabında verdiği oturum örneklerinde Adıgüzel gibi işlevsel ve yalın bir planlama yaklaşımı sunmaktadır. McCaslin, öğrenme kazanımlarına ayrı bir bölüm olarak yer verirken, süreci hazırlık ve işleyiş olarak ikiye ayırmıştır. İşleyişi de kendi içerisinde canlandırma ve değerlendirme bölümlerine ayırmak olanaklıdır. Yaratıcı drama alanındaki çeşitli planlama yaklaşımları değerlendirildiğinde; Adıgüzel'in yaklaşımını uluslararası planlama ve yapılandırma basamaklarını içeren, yaratıcı dramanın alan bilgisine sahip herkesin kullanabileceği işlevsel bir yaklaşım olarak tanımlamak mümkündür.

Adıgüzel'in (2006) yaratıcı drama çalışmaları için kendi deyimiyle "geliştirilen ve önerilen" aşamaları aşağıdaki gibidir:

- Hazırlık-Isınma Çalışmaları

- Canlandirma

- Değerlendirme-Tartışma.

Adıgüzel (2018) kendi planlama ve yapılandırma yaklaşımının plan künyesinde ise "Ders, konu, kazanımlar, süre, sınıf (çalışılacak grup), araç-gereçler, yöntem ve teknikler” başlıklarına yer vermiştir. Adıü̈zel'in (2018 s.134-135) planlama ve yapılandırma yaklaşımının genel çerçevesi aşağıdaki gibidir:

"Yaratıcı drama çalışmalarında ne, niçin, ne zaman, nasll, nerede, kim, kime (kimlerle) gibi sorulara verilecek yanıtlar, yaratıcı drama sürecinin tüm yapılandırmasinı ya da izlenecek aşamalar zincirini oluşturur.

Yaratıcı drama çalışmalarında önemli olan saptanan amaçlara göre işlenecek konunun uygun olan gruba ve gereken zamanda verilirken tüm etkinlikler arasında bir bağlantının olmasl, etkinliklerin bir birini destekleyen ve bütünleyen bir özelliğinin sahip olması ve katılımcıda içselleştirilmesi düşünülen kazanımlara ulaşmada etkili olup olmayacağının belirlenmesidir."

"Yaratıcı Dramayı Planlama ve Yapılandırmada Adıgüzel Yaklaşımı" örnek yaratıcı drama planı şablonuna makalenin ekinde yer verilmiştir. Bu çalışmaya katılan öğretmen adaylarına ders kapsamında aktarılan ve öğretmen adaylarının ders planlarını geliştirirken bağlı kaldıklarını yapılandırma yaklaşımı Adıgüzel'e ait olan yaklaşımdır. Öğretmen adaylarının planları ve planlamada karşılaştıkları sorunlara ilişkin elde edilen veriler Adıgüzel'in yaklaşımı ölçüt alınarak değerlendirilmiş ve yorumlanmıştır. 


\section{Bulgular}

Bulgular önceden belirlenmiş iki tema altında toplanmıştır. $\mathrm{Bu}$ temalar; "Öğretmen Adaylarının Yaratıcı Drama Planı Oluştururken Bağlı Kaldıkları Ölçütler” ve “Öğretmen Adaylarının Yaratıcı Drama Planı Oluştururken Karşılaştıkları Sorunlar”dır. Planlama sürecinde bağlı kalınan ölçütlerin belirlenmesi, öğretmen adaylarının oluşturdukları yaratıcı drama planlarının araştırmada bağlı kalınan planlama yaklaşımına uygun olup olmadıklarını değerlendirmek açısından gerekli görülmüştür.

\section{1. Öğretmen Adaylarının Yaratıcı Drama Planı Oluştururken Bağlı Kaldıkları Ölçüitlere İlişkin Bulgular}

Öğrencilerin yaratıcı drama planı geliştirirken bağlı kaldıkları ölçütler teması altında oluşmuş kategorilere bakıldığında; "öğrencinin gelişim düzeyine uygunluk", "aşamalılığa ve kazanıma/kazanımlara bağlı kalmak" başlıklı alt kategorilerin ortaya çıktığı görülmektedir. Öğretmen adaylarının yaratıcı drama planı oluştururken bağlı kaldıkları ölçütler başlıklı temaya ait alt kategoriler ve bu alt kategorilere ait kodlar öğretmen adaylarının görüşlerinden yapılan doğrudan alıntılarla yorumlanarak sunulmuştur. Aşağıda temanın iki alt kategorisini gösteren tablo bulunmaktadır:

Tablo 1. Öğretmen Adaylarının Yaratıcı Drama Planı Oluştururken Bağlı Kaldıkları Ölçütler

\begin{tabular}{cl}
\hline $\begin{array}{c}\text { Öğretmen Adaylarının } \\
\text { Yaratıcı Drama Planı Oluştururken } \\
\text { Bağlı Kaldıkları Ölçütler }\end{array}$ & Öğrencinin Gelişıim Düzeyine Uygunluk \\
\cline { 2 - 2 } & Aşamalılığa ve Kazanıma/Kazanımlara Bağlı Kalmak \\
\hline
\end{tabular}

Öğretmen adaylarının yaratıcı drama planı oluştururken bağlı kaldıkları ölçütler temasının ilk alt kategorisi "Öğrencinin Gelişim Düzeyine Uygunluk" tur. Bu kategorinin altında toplanan ortak kodlar aşağıdaki gibidir:

Tablo 2. Öğrencinin Gelişim Düzeyine Uygunluk

\begin{tabular}{cl}
\hline $\begin{array}{c}\text { Öğrencinin } \\
\text { Gelişim Düzeyine } \\
\text { Uygunluk }\end{array}$ & $\begin{array}{l}\text { Seçilen Oyun, Etkinlik ve Canlandırmaların Öğrencinin Gelişim Düzeyine } \\
\text { Uygunluğu }\end{array}$ \\
\cline { 2 - 2 } & Öğrencinin Gelişim Düzeyine Uygun Dil Kullanımı \\
\cline { 2 - 2 } & Öğrencinin Gelişim Düzeyine Uygun Materyal Seçimi \\
\hline
\end{tabular}

$\mathrm{Bu}$ alt kategoride, öğrencilerin yaratıcı drama planı oluştururken bağlı kaldıkları ölçütleri karşılayan kodlar; seçilen oyun, canlandırma ve etkinliklerin öğrencinin gelişim düzeyine uygun olması, öğrencin gelişim düzeyine uygun materyalin seçimi ve dilin kullanımı başlıklarında toplanmıştır. Öğretmen adaylarının yaratıcı drama oturumlarını geliştirirken hedef kitle olarak belirledikleri yaş grubunun bilişsel ve dilsel gelişim düzeyini de dikkate aldıkları görülmektedir:

"Dramatik durumu yazarken ögrencinin bilişsel seviyesine göre yazmaya dikkat ettim. Oyun seçimlerinde ilk olarak çocukların farkındalık bilincinin gelişimine dikkat ettim. Öğrencilerin anlayabileceği bir dil kullanmaya çalıştım. Aynı zamanda öğrenciyi slkmadan eğlenceli bir şekilde öğrenmelerini ve bu durumlara çözüm yolları bulmalarını sağlamaya çalıştım.'” (ÖA1) 
"Dramatik durumu yazarken öğrencinin bilişsel seviyesine göre yazmaya dikkat ettim. Onların anlayabileceği bir dil kullanmaya gayret ettim. Ayn zamanda etkinlikler yaparken ögrrencinin ilgisini çekecek, günlük hayatta karşılarına çıkabilecek ve onlara bu saygı kavramı bilincini aşılayabilecek etkinlikler, durumlar seçmeye çalıştım. "(ÖA6)

Atölyelerde, katılımcı grubun dilsel gelişim düzeyine uygun bir eğitmenlik tavrı belirlemek önemlidir. Çünkü seçilen oyunlar, canlandırma durumlarını birbirine benzer olsalar da bu etkinliklerin katılımcı gruba aktarım dili yaş grubuna göre değişir. Eğitmen, okulöncesi dönem çocuklarıyla yapılan bir atölyede daha kısa, yalın sözcükler seçerek yönerge vermek durumundayken, yetişkinliklerle yapılan atölyelerde daha uzun, karmaşık ve yetişkinliklerin dağarcığına uygun sözcükler seçebilir.

Öğretmen adaylarının özellikle bağlı kaldıklarını ifade ettikleri bir diğer ölçüt ise materyal seçimi olmuştur:

“... canlandırmanın ikinci etkinliğimde kullandı̆̆ım görsellerde öğrencileri duygusal anlamda zedeleyecek olmamasına dikkat ettim. Kullandığım görsellerde toplumun engelli bireylerin hayatını zorlaştıracak durumlarını ele aldım. Öğrencilerden bu olumsuz durumlarla nasıl başa çıkacaklarını kendilerinin bulmasını istedim. Bu yüzden ikinci etkinlikte ögrencilere dramatik durum vermedim. Seçtiğim her iki kazanıma bağlı kalarak atölyemi oluşturdum." (ÖA4)

ÖA4'ün örnek ifadesinden yola çıarak öğretmen adaylarının çoğunluğunun materyal seçerken uygulama yapacakları yaş grubunun duygusal ve psikolojik gelişim düzeylerini dikkate aldıkları, işlenen konuyla ilgili yanlış duyarlılık geliştirmeye yol açabilecek materyal kullanımlarından kaçındıkları ifade edilebilir.

"Videoyu seçerken o yaş grubuna uygun olmasina dikkat ettim. Çocuk edebiyatından da ögrrendiğim üzere 'çocuğa görelik ilkesi' çok önemli. Video seçerken belirlediğim konudan (şiddetle ilgili) dolayı da çok dikkatli olmam gerekiyordu. Araç-gereç seçerken çocuğun dikkatini çekebilecek malzemeler olmasına dikkat ettim (renkli kâğıt, boya kalemi vb.) Dramatik durum seçerken canlandırmalar esnasında çocukların birbirine zarar vermeyeceği durumlar olmasına dikkat etmeye çalıştım. Çatışmalarda her iki tarafin da haklı olabileceği durumları seçmeye çalıştım." (ÖA8)

Yaratıcı drama süreçlerinde materyal (araç-gereç) seçimi atölye planlama künyesindeki birimlerden biri olup ele alınan konunun öğretilmesine yardımcı olacak biçimde belli bir amaç ve katılımcılara uygunluğu doğrultusunda seçilir. Öğretmen adayları materyal seçiminde yaş grubuna uygunluk ve materyalin konuyla ilişkili olması ölçütlerine bağlı kaldıklarını dile getirmişlerdir.

Öğretmen adayları yaratıcı drama ders planlarını geliştirirken bağlı kaldıkları bir diğer ölçütün kazanıma/kazanımlara ve aşamalara (1sıma-hazırlık/canlandırma/değerlendirme-tartışma) bağlılık olduğunu ifade etmişlerdir. Bu alt kategorinin kodlarına aşağıdaki tabloda yer verilmiştir: 
Tablo 3. Aşamalılı̆̆a ve Kazanım/Kazanımlara Bağlı Kalma

\begin{tabular}{cl}
\hline Aşamalıı̆̆a ve & Isınma-Hazırlık Aşaması \\
Kazanıma/ & Canlandırma Aşaması \\
Kazanımlara & Değerlendirme-Tartışma Aşaması \\
\cline { 2 - 2 } Bağlı Kalmak & Kazanıma Uygun Materyal Seçimi \\
\hline
\end{tabular}

Öğretmen adaylarının bu kategori için bağlı kaldıklarını vurguladıkları bu ölçütler; Adıgüzel planlama yaklaşımının da en önemli iki temel ilkesidir. Adıgüzel yaratıcı drama planlama yaklaşımında, belirlenen kazanım birbiriyle bağlantılı aşamalar halinde ele alınarak irdelenir. $\mathrm{Bu}$ yüzden, kazanımlara bağlı kalmakla, aşamaların birbiri arasındaki ve kazanımla ilişkisini gözetme konuları iç içe geçmiştir. Bunun yanında, öğretmen adaylarının 1sınma-hazırlık için seçtikleri etkinliklerin kazanımla ilişkili olmasına, sonraki aşamalara hazırlık niteliği taşımasına dikkat ettiklerini ifade etmişlerdir:

"Atölyenin içeriğini geliştirirken dersin başında kullandığım videonun, ısınma aşamasında kullandı̆̆ım oyunun, canlandırma aşamasında önceden yazılmış olarak aldığım ve kendim yazdığım dramatik durumların seçtiğim konuyla ve kazanımla ilişkili olmasına, hitap ettiğim yaş grubuna uygun olmasına ve ögrencilere kazandırmak istediğim bilinci en etkili şekilde kazandırmasina yani işlevsel olmasına dikkat ettim." (ÖA19)

"Isınma aşaması için düşündügüm oyunu kazanımla iliş̧kilendirdim. Dramatik durum yazarken çatışmalar içermesi, işlevselliği önemliydi." (ÖA22)

Öğretmen adayları, canlandırma aşamasında ise çatışma içeren dramatik durumlar yazma, bu dramatik durumlar içerisinde yer alan roller arasında güç-statü dengesini gözetme, dramatik durumların konularını gündelik yaşamla ilişkilendirmeye çalışma gibi ölçütlere bağlı kaldıklarını ifade etmişlerdir:

"Dramatik durum seçerken canlandırmalar esnasında çocukların birbirine zarar vermeyeceği durumlar olmasına dikkat etmeye çalıştım. Çatışmalarda her iki tarafin da haklı olabileceği durumları seçmeye çalıştım." (ÖA8)

Öğretmen adaylarının en az değindikleri aşama ise değerlendirme aşaması olmuştur. Bu aşama için görüş belirten öğretmen adayları kazanıma ulaşılıp ulaşılmadığını değerlendirmek adına ara değerlendirmeler de yaptıklarını, değerlendirme aşaması için ise sorular hazırladıklarını ifade etmişlerdir:

“...Canlandırmalarımda çatışmalara ve konumla alakalı olmasına, ısınma aşamasında canlandırmaya hazırlık yaptırmaya buna temel oluşturmaya dikkat ettim. Değerlendirme aşamasında ise soruları hazırlarken ara değerlendirme ve genel değerlendirme yapmaya dikkat ettim." (ÖA5)

Öğretmen adaylarının planlama sürecinde dikkat ettikleri bir diğer nokta ise kazanıma uygun materyal seçimi olmuştur. Öğretmen adayları, atölyelerinde kullanmak için belirledikleri materyal ya da materyallerin uygulama yapılacak grubun gelişim düzeyine uygunluğunun yanında, kazanıma da hizmet etmesi gerektiği yönünde görüş belirtmişlerdir:

"Isınma aşaması için 'Pusulacık: Çocuklar İçin İnsan Hakları Eğitimi Kılavuzu'nun 'Erkekler Ağlamaz'metninden yararlandım. Birkaç kısmını değiştirdim. Metni seçerken konu ile bağlantılı olması için toplumsal cinsiyet eşitliği kazanımını sağlayacak oyunları seçtim” (ÖA9) 
ÖA9'un ifadesinde de görülebileceği gibi öğretmen adayı kendi oturumu için seçtiği materyali kazanımıyla ilişkisi odağında seçmiştir. Bunun yanında, yaratıcı drama süreçlerinin gereği olarak metni birebir sürece dahil etmek yerine, metin üzerinde değişikliklere gitmiştir. Öğretmen adayları seçtikleri materyallerin kazanıma uygunluğunu gözettikleri gibi seçilen materyalin aşılayabileceği değerleri ve görüşleri de gözetmişlerdir:

“...seçtiğim materyalleri kazanıma uygunluğu açısından değerlendirdim. İçerisinde ırkçı ya da yanlış kelimelerin geçip geçmediğine dikkat ettim. Ë̆itici olan çalışmalar seçmeye çalıştım." (ÖA27)

Öğretmen adaylarının kendi planlarını geliştirirken bağlı kaldıkları ölçütler değerlendirildiğinde, ölçüt alınmış yaratıcı drama yaklaşımının planlama ilkelerini asgari düzeyde karşılayan planlar geliştirmiş oldukları sonucuna ulaşılabilir. Adıgüzel'in yaratıcı drama planı yapılandırma yaklaşımında, belirlenen bir kazanımın birbiriyle bağlantıları kurulmuş üç aşama içerisinde sürece dayalı ele alınması söz konusudur. Öğrencilerin planlama yaparken bağlı kaldıkları ölçütler kazanıma uygunluk ve aşamalar arasında kazanımla ilişkili bağlantılar kurmuş olmaları planlamada asgari düzeyde dikkat edilmesi gereken noktaları göz önünde bulundurduklarını göstermektedir. Bunun yanında, öğretmen adaylarının görüşlerinden yapılan doğrudan alıntılarda gelişim düzeyine, kazanımlara, aşamalılığa bağl1lık gibi durumlarda bir iç içe geçmişlik durumunun söz konusu olduğu göze çarpmaktadır. Bu durum da öğretmen adaylarının planlarında uygun ölçütleri gözettiklerinin bir diğer göstergesidir. Çünkü belirlenen kazanımın atölyenin beraber gerçekleştirileceği katılımcı grubun özelliklerine uygun olması, seçilecek materyallerin ve etkinliklerin de katılımcı grubun özelliklerine uyumlu olmasını da beraberinde getirir. Bu ölçüte bağlı kalırken, bir yandan da aşamaların birbiriyle olan ilişkisinin kurulması da gerekir. Tüm bunlar gerçekleştirildiğinde ise planlamada bağlı kalınan ölçütler bir bütünü oluşturacak biçimde iç içe geçmiş olurlar.

\section{2. Öğretmen Adaylarının Yaratıcı Drama Planı Oluştururken Karşılaştıkları Sorunlara İlişkin Bulgular}

Öğretmen adaylarının yaratıcı drama planı geliştirme süreçlerinde karşılaştıkları sorunlar üç ana kategori altında toplanmıştır. Bu kategoriler, "motivasyon eksikliğinden kaynaklı sorunlar", "yaratıcı drama alanına ilişkin bilgi eksikliğinden kaynaklı sorunlar", "planda ele alınan konuya ilişkin bilgi eksikliğinden kaynaklı sorunlar" olarak belirlenmiştir:

Tablo 4. Öğretmen Adaylarının Yaratıcı Drama Planı Oluştururken Karşılaştıkları Sorunlar

\begin{tabular}{|c|c|c|}
\hline \multirow{2}{*}{$\begin{array}{c}\text { Öğretmen } \\
\text { Adaylarının } \\
\text { Yaratıcı Drama }\end{array}$} & \multirow{2}{*}{$\begin{array}{l}\text { Motivasyon } \\
\text { Eksikliğinden } \\
\text { Kaynaklı Sorunlar }\end{array}$} & Motivasyon Eksikliğine Neden Olan Çevresel Etkenler \\
\hline & & Motivasyon Eksikliğine Neden Olan Bireysel Etkenler \\
\hline \multirow{2}{*}{$\begin{array}{c}\text { Planı Oluştururken } \\
\text { Karşılaştıkları } \\
\text { Sorunlar }\end{array}$} & \multicolumn{2}{|c|}{ Yaratıcı Drama Alanına İlişkin Bilgi Eksikliğinden Kaynaklı Sorunlar } \\
\hline & \multicolumn{2}{|c|}{ Planda Ele Alınan Konuya İlişkin Bilgi Eksikliğinden Kaynaklı Sorunlar } \\
\hline
\end{tabular}

Motivasyon eksikliği, öğretmen adayları tarafından planlama sürecinde karşılaştıkları sorunlardan biri olarak sıkça ifade edilmiştir. Öğretmen adaylarının motivasyon eksikliğine ilişkin görüşleri "motivasyon eksikliğine neden olan çevresel etkenler" ve "motivasyon eksikliğine neden 
olan bireysel etkenler" olarak iki başlık altında toplanmıştır. Öncelikle motivasyon eksikliğine neden olan çevresel etkenler ele alınmıştır:

Tablo 5. Motivasyon Eksikliğine Neden Olan Çevresel Etkenler

\begin{tabular}{cl}
\hline Motivasyon & Yaratıcı Drama Dışındaki Derslerin Sorumlulukları \\
Eksikliğine & \\
\cline { 2 - 2 } $\begin{array}{c}\text { Neden Olan } \\
\text { Çevresel } \\
\text { Etkenler }\end{array}$ & Sınav Haftası Yoğunluğu \\
\hline
\end{tabular}

Öğretmen adayları, yaratıcı drama dışında aldıkları derslerde üstlendikleri sorumluluklar (ödev, sunum, alttan çok fazla ders almak vd.) ve yaratıcı drama planı ödevinin tesliminin sınav haftasına denk gelmesinden doğan bir motivasyon eksikliği yaşadıklarını ifade etmişlerdir:

"Yaşadığım en büyük zorluk motivasyon eksikliği oldu. Ama bu kesinlikle sizinle ya da ödevle ilgili bir durum değil, çevresel kaynaklyydı. Hem bir sürü sunumumuz vardı hem de bir sürü sınavımız... Bir türlü kendimi hazır hissedemedim ve başlayamadım. İstediğim gibi üzerinde uzun uzun düşünemedim. Bu durumu zamanı biraz daha verimli kullanarak aşmaya çalıştım. Ama işe yaramadl." (ÖA8)

ÖA8'in ifadesinden de anlaşılabileceği gibi öğretmen adaylarından bazıları planlama sürecinde yaşadıkları en büyük sorunu motivasyon eksikliği olarak tanımlamışlardır. Motivasyon eksikliğinin en önemli nedeni ise öğretmen adaylarının diğer derslerden kaynaklı yoğunluklarının yarattı̆̆ zaman sıkıntısıdır. Zaman sıkıntısı beraberinde yetiştirme kaygısını da getirdiği için öğretmen adayları planlarına ilişkin sağlıklı düşünemediklerini ifade etmişlerdir. Bunun yanında, öğretmen adaylarının sınavlardan, ödevlerden, sunumlardan kaynaklı yoğunluklarının yaratıcı drama alan bilgisini de yeterli düzeyde araştırmalarına engel olduğu söylenebilir. Bu durum mevcut motivasyon eksikliğini besleyen bir diğer kaynak olarak ortaya çıkmıştır:

"Atölye içeriğini geliştirirken çok zorlandım. Tam final haftasına denk gelmişti, zaman bulamadım, odaklanamadım, dramatik durum oluşturmakta zorlandım, alan bilgim yetersizdi, stres ve motivasyon düşüklüğ̈̈nden dolayı sağllklı düşünemedim. Bu yüzden parça parça ilerlemek zorunda kaldım. Öncesinde verilmiş olsaydı daha iyi bir şekilde keyifle hazırlayacağımı düşünüyorum. Stresli bir zamanda bu kadar yol alabildim. Ödevimi rahat, huzurlu ve zamanım bol olduğu günlerde hazırlamayı çok isterdim. Eminim daha güzel bir plan ortaya çıkardl." (ÖA27)

Öğretmen adayları, yaratıcı drama planlama sürecinde çevreden kaynaklı motivasyon eksiklikleri yaşadıkları gibi bireysel etkenlerden kaynaklı motivasyon eksikliği yaşadıklarını ifade etmişlerdir. Ev ve okul arasındaki mesafe, yorgunluk, aileyi uzun zamandır ziyaret edememe, kendine güvensizlik gibi geniş bir yelpazede konumlanan bireysel etkenlere aşağıdaki tabloda yer verilmiştir: 
Tablo 6. Motivasyon Eksikliğine Neden Olan Bireysel Etkenler

\begin{tabular}{ll}
\hline $\begin{array}{c}\text { Motivasyon } \\
\text { Eksikliğine } \\
\text { Neden Olan } \\
\text { Bireysel } \\
\text { Etkenler }\end{array}$ & Ev ve Okul Arası Mesafenin Uzak Olması \\
\cline { 2 - 2 } & Könem Sonu Yorgunluğu \\
\cline { 2 - 2 } & Aileyi Uzun Zamandır Ziyaret Etmemiş Olmak \\
\cline { 2 - 2 } & Odaklanamama/Dikkat Eksikliği \\
\hline
\end{tabular}

ÖA8 evi ve okul arasındaki mesafenin uzaklığından, yolun çok fazla zamanını almasından yakınırken, bu durumun yorgunluğa, zaman sıkıntısına neden olduğunu ifade etmektedir:

“...okuldan eve gelmem yaklaşık 1,5 saat sürüyor. Eve geldiğimdeyse aşırı yorulmuş oluyorum ve hiçbir şeye vakit ayıramıyorum. Ama zaman esnekliği sağladığını için daha fazla düşünme imkânım oldu, çok teşekkür ederim." (ÖA8)

ÖA16 ise düşündüklerini yazıya aktarma konusunda sıkıntılar yaşadığını ifade etmektedir:

"Kitapları okurken kafamda bir sürü olaylar,dramatik durumlar canlanırken keyifli olan bu süreç atölye içeriğiyle birlikte oluşturacağım ders planı sürecinde galiba o kadarda keyifli değildi. Bilgisayarın başına geçip düşündüklerimi,incelediklerimi yazmak beni oldukça zorladı.Bunun bence en büyük sebebi dönemin bitmesiyle birlikte üzerimde hissettiğim yorgunluğunda etkisiyle motivasyonumun son derece düşük olmaslydl."

ÖA32'nin bireysel motivasyon eksikliği ise alana ilişkin bilgi yetersizliğinden kaynaklanmaktadır. Bu durum öğretmen adayında iyi bir plan ortaya koyamama kaygısını beraberinde getirmektedir:

"Atölyeyi oluştururken bu alanda bilgi yetersizliğim olduğu ve konuya tam hakim olamayışım etkili olmuştur.Motivasyon tam olarak olamıyor ben de çünkü kendim çok iyi şeyler ortaya çılkarabilme konusunda açıkçası güvenmiyorum.Hemen bir kopukluk oluyor ben de bir şeyleri uzun sürede dikkatli bir şekilde yapma yeteneği yoktur.Dikkat dă̆llması çok olduğu için ben de bazı şeyleri unutabiliyorum maalesef." (ÖA32)

Bir başka öğretmen adayı ise yaşadığı motivasyon eksikliğini ailesini uzun zamandır ziyaret edememesine bağlamaktadır:

"Motivasyon eksikliği yaşadım açıkçası yaşamam nedeni ailemin yanına gidemememdi ama sonradan toparladım ve açıkçası iki hafta bu ödev için düşündüm. ” (ÖA21)

Öğretmen adaylarının yaşadıkları bireysel motivasyon eksikliği çok çeşitli etkenlere dayanmaktadır. Bunun yanında, motivasyon eksikliği teması göstermektedir ki iyi bir yaratıcı drama planı yapabilmek için alanla ilgili yeterli bilgi sahibi olmanın yanında planlamayı yapan kişiyi hem çevresel hem de bireysel olarak motive eden koşullarında bulunması gerekmektedir. 
Tablo 7. Yaratıcı Drama Alanına İlişskin Bilgi Eksikliğinden Kaynaklı Sorunlar

\begin{tabular}{|c|c|c|}
\hline \multirow{3}{*}{$\begin{array}{c}\text { Yaratıcı Drama } \\
\text { Alanına İlişkin } \\
\text { Bilgi Eksikliğinden } \\
\text { Kaynaklı Sorunlar }\end{array}$} & $\begin{array}{l}\text { Aşamaları } \\
\text { Yapılandırmayla İlgili }\end{array}$ & Isınma-Hazırlık Aşaması \\
\hline & Yaşanan Sorunlar & Canlandırma Aşaması \\
\hline & & Değerlendirme-Tartıșma Așaması \\
\hline
\end{tabular}

Öğretmen adayları planlama süreçlerindeki sorunlardan birini yaratıcı drama alanına ilişkin bilgi eksikliği olarak ifade etmişlerdir. Bu bilgi eksikliğinin özellikle aşamaları kendi içerisinde yapılandırırken, aşamaların birbirleriyle ilişkisini kurarken soruna neden olduğunu aktarmışlardır. Isınma-hazırlık aşamasında yaşanan en büyük sorunlardan biri kazanıma uygun oyun ve etkinlik bulmak, 1sınma-hazırlık aşamasını etkili ve dikkat çekici kılmak olarak öne çıkarken, canlandırma aşamasındaki en büyük sorunlardan biri olarak da dramatik durum yazmak olarak gösterilmiştir. Bunun yanında, öğretmen adayları değerlendirme-tartışma aşamasına da uygun değerlendirme etkinliği yazma konusunda sorunlar yaşadıklarını dile getirmişlerdir.

Öğretmen adaylarının yaratıcı drama alanına ilişkin bilgi eksikliğinden kaynaklı yaşadıkları sorunların başında aşamaların içeriğini yapılandırabilecek uygun etkinlikleri bulabilmek ve oluşturabilmek gelmektedir. ÖA1, 1sınma ve değerlendirme aşamalarına uygun, kazanımla ilişkili etkinlikler bulmakta zorlandığını ifade etmektedir:

"Atölye içeriğini geliştirirken özellikle ısınma ve değerlendirme aşamalarında öğrencinin ilgisini canlı tutacak ve ögrenciye yardımlaşma bilinci kazandıracak etkinlikler bulmak zamanımı aldı."

ÖA6 ise daha çok 1sınma-hazırlık aşamasını etkili hale getirme konusunda sıkıntı yaşadığını ifade etmektedir:

"Atölye içeriğini gelişstirirken birkaç yerde zorluklar yaşadım. Isınmayı etkili hale nasıl getiririm öğrencinin dikkatini nasll çekerim diye düşündüm."

Öğretmen adaylarının yaratıcı drama alanına ilişkin bilgi eksikliklerinden kaynaklı yaşadıkları sorunların en önemlilerinden birisi de canlandırma aşamasının yapılandırılmasıdır. Canlandırma aşamasının yapılandırılması bağlamında en çok değinilen sorun ise dramatik durum yazamama olarak ifade edilmiştir.

Ancak dramatik durum yazamamak öğretmen adayları tarafından zaman zaman farklı gerekçelerle dile getirilmiş, bazı öğretmen adayları ise bu konuda hiç gerekçe belirtmemiştir. ÖA9, dramatik durum yazamamasının nedeni olarak atölyesinin konusuyla ilgili yalnızca gündelik yaşamdan edindiği bilgilere sahip olduğunu, konuyla ilgili akademik bilgiye sahip olmadığını ifade etmiştir. Bu durumun da dramatik durum yazmasında sorun yaşamasına neden olduğunu aktarmıştır:

"Atölye içeriğini geliştirirken zorluk yaşadım. Çünkü bu konuya yaşantı olarak hakimim fakat pek fazla bilgi birikimim yok. Canlandirmalarım için dramatik durum kurgularken zorluk yaşadım. Bunları aşmak için kaynaklara başvurdum."

ÖA22'nin dramatik durum yazma ile ilgili yaşadığı sorun ise daha çok dramatik kurgunun bileşenlerinin doğru bir biçimde bir araya getirilmesiyle ilgili görünmektedir. Özellikle ÖA22'nin ele aldığ 1 "şiddet" gibi çatışmalı toplumsal konularda, roller arasındaki statü, güç dengesini kurmak, dramatik kurgunun bileşenlerini bir araya getirmek daha da zorlaşmaktadır: 
"En çok ise dramatik durumlar yazarken zorlandım. Konu şiddet olunca şiddet uygulayan tarafin bir haklıliğ kalmiyor. Dramatik durum bu kez uygun olmuyor. Bu durumlarl yazarken başka konu mu seçsem diye bile düşündüm. Ama iyi kötü durumlart yazdım." (ÖA22)

ÖA27 ise dramatik durum yazarken yaşadığ1 zorluğu herhangi bir gerekçe belirtmeden doğrudan alan bilgisi eksikliğiyle ilişkilendirmektedir:

"Dramatik durum yazarken zorlandım .buda bu alanda fazla bilgi sahibi olmaylşımdan kaynaklaniyor." (ÖA30)

Öğretmen adayları yaratıcı dramaya ilişkin alan bilgisi eksikliğinden kaynaklı sorunların yanında, "Planda Ele Alınan Konuya İlişkin Bilgi Eksikliğinden Kaynaklı Sorunlar" yaşadıklarını da ifade etmişlerdir. Aslında bu iki konudaki bilgi eksikliğinin birbirinden ayrı düşünülmemesi gerekir. İyi bir yaratıcı drama planı geliştirmek için hem yaratıcı drama alan bilgisine hem de atölyenin konusuna ilişkin bilgiye sahip olmak gerekir. Öğretmen adaylarının bu konuda yaşadıkları sorunlar iki başlık halinde ele alınabilir. Kimi öğretmen adayı atölyesinde ele aldığı konuya ilişkin bilgi eksikliğinden yakınırken, kimi öğretmen adayı ise atölyesinde ele aldığı konuya ilişkin başvurulacak kaynakların azlığından, kaynaklara ulaşmanın zorluğundan söz etmiştir.

"Atölye içeriğini geliştirirken zorluk yaşadım. Ayrıca seçtiğim konu zor geldi bu konuyla ilgili nasll bir atölye tasarlamam gerektiğini bulmakta zorlandım. "(ÖA34)

"Atölyeyi oluştururken bu alanda bilgi yetersizliğim olduğu ve konuya tam hakim olamayışım etkili olmuştur." (ÖA32)

ÖA34 ve ÖA32, yalnızca atölyelerine seçtikleri konuya ilişkin bilgi sahibi olmadıklarından sorun yaşadıklarını ifade etmişlerdir. ÖA22 ise daha kapsamlı bir araştırma gereksinimi duyduğunu ancak koşullardan kaynaklı başaramadığını ifade etmiştir:

"Evet yaşadım. Alan hakkinda sadece gündelik bilgilere sahiptim. Final sinavları olması sebebiyle daha kapsamlı ve daha çok araştırma yapacağım bir konuyu daha kısa bir zamanda ve sinırl kaynaklarla yaptım."

ÖA31 ve ÖA19 ise atölyenin konusuna ilişkin kaynakların azlığından ve bu kaynaklara ulaşımın zorluğundan kaynaklı sorunlar yaşadıklarını ifade etmişlerdir:

"Hocam aslında yaşadım. Bu konuyla ilgili ya çok az makale yazılmış ya da internette yoktu. Umarım sadece internete konmamıştır. Eğer yok bu konu üzerinde durulmamışsa zaten vay bizim halimize diyorum hocam. Baş etmeye çalıştım okulumuz kütüphanesinde de kaynak bulamadım. Birkaç kitap varmış ama onlarda alınmış daha getirilmemişti." (ÖA31)

"Atölye içeriğini oluştururken alanla ilgili bilgi yetersizliği konusunda sorun yaşadım. Sadece bu konuda yazılmış bir makale bulamadım. Bu nedenle konuyla iliş̧kili olduğunu düşündüğ̈̈m makalelerin hepsini okumak zorunda kaldım ve bilgileri onlardan parça parça aldım. Bu durum zamanımı aldı ama sonunda ödevimi bitirdim." (ÖA19)

Öğretmen adaylarının hem yaratıcı dramaya hem de ele aldıkları konuya ilişkin bilgi eksikliklerinin birbirini olumsuz etkilediği ifade edilebilir. Yaratıcı drama, katılımcıların yaşantılarından yola çıkar. Bu yaşantılar, dramatik bir kurgu içerisinde derinlemesine irdelenir. $\mathrm{Bu}$ yüzden, ele alınan konuya ilişkin derinlikli bilgiye sahip olmayan bir yaratıcı drama eğitmeni, o konuyla ilgili sağlam bir dramatik kurgu yaratmak konusunda da sorunlar yaşayabilir. Öğretmen adaylarının kendi yaratıcı drama planlarında ele aldıkları konulara ilişkin bilgilerinin olmamasının, dramatik durum yazma süreçlerini de olumsuz etkilediği söylenebilir. 


\section{Tartışma, Sonuç ve Öneriler}

Sınıf öğretmenliği adaylarının yaratıcı drama ders planı geliştirirken karşılaştıkları sorunların incelenmesi amacıyla gerçekleştirilen bu çalışmanın sonucunda, öğretmen adaylarının bu süreçte çeşitli sorunlar yaşadığı belirlenmiştir. Öğretmen adaylarının zorunlu olarak aldıkları drama dersi kapsamında gerçekleştirilen çalışmada, ilk adım olarak yaratıcı drama planlama süreçlerinde bağlı kaldıkları ölçütler "Yaratıcı Dramayı Planlama ve Yapılandırmada Adıgüzel Yaklaşımı" yaklaşımın ilkelerine göre değerlendirilmiştir. Böylece geliştirilen yaratıcı drama planının asgari şartları taşıyıp taşımadığı anlaşılmaya çalışılmıştır. Öğretmen adaylarının kendi planlarını geliştirirken bağlı kaldıkları ölçütler değerlendirildiğinde, ölçüt alınmış yaratıcı drama yaklaşımının planlama ilkelerini asgari düzeyde karşılayan planlar geliştirmiş oldukları ifade edilebilir.

Adıgüzel'in yaratıcı drama planı yapılandırma yaklaşımında, belirlenen bir kazanımın birbiriyle bağlantıları kurulmuş üç aşama içerisinde sürece dayalı ele alınması anlayışının incelenen tüm planlarda gerçekleştirildiği görülmektedir. Bu bağlamda, öğretmen adaylarının yaratıcı drama planı geliştirmeyle ilgili temel bir fikir edindikleri söylenebilir. İkinci adımda, öğretmen adaylarının hazırladıkları planlara ilişkin yaşadıkları sorunlar, ölçüt olarak belirlenen yaratıcı drama planlama yaklaşımının ilkelerine göre değerlendirilmiştir. Her ne kadar geliştirilen planlar ölçüt olarak belirlenen yaratıcı drama yapılandırma yaklaşım şablonuna biçimsel olarak uygun hazırlanmışsa da planlarda hala eksiklikler olduğu göze çarpmaktadır. Öğretmen adaylarının da ifade ettiği gibi bu eksiklikler genel olarak yaşadıkları motivasyonsuzluktan, yaratıcı drama alan bilgisi ve uygulamaların içeriğini oluşturan konulara ilişkin bilgi eksikliğinden kaynaklanmaktadır.

Çalışmanın sonuçlarından motivasyon eksikliği özellikle dikkate değerdir. Çalışmanın sonuçları göstermektedir ki yaratıcı drama süreçlerini planlamada masa başında gerçekleştirilen çalışmalar kadar planı yapanın koşullarından ve bireysel durumundan kaynaklanan motivasyonunun da önemli olduğu ortaya çıkmıştır. Çalışmada, öğretmen adaylarının yaşadıkları sorunlar ayrı ayrı kategorize edilmiş olsalar da belli noktalarda iç içe geçmekte, kesişmektedirler. Yaratıcı dramaya ve yaratıcı drama planlaması yapmak için seçilen kazanımı kapsayan konuya ilişkin bilgi eksikliğinin yapılması amaçlanan işe dönük bir yetersizlik duygusu yarattığı ifade edilebilir. Bu yetersizlik duygusunun ise öğretmen adaylarında planlamayı gerçekleştiremeyeceklerine ilişkin bir kaygıya, motivasyon eksikliğine dönüştüğü söylenebilir. Bu durum, yaratıcı drama dersinin içeriğinin bir dönemlik derste verilemeyecek kadar yoğun olmasından da kaynaklanıyor olabilir. Aslında yaratıcı dramanın temel kavramlarına, planlama ve uygulama anlayışına ayrılacak bir dönemlik dersin ardından, bir başka dönemde de yalnızca uygulamaya dönük bir drama dersinin olması öğretmen adaylarının yaratıcı dramanın alan bilgisini daha geniş bir zamanda ve derinlemesine öğrenmelerini sağlayabilir. Ancak bu çalışmada tespit edilen sorunlar yumağının önümüzdeki yıllarda öğretmen adaylarının yaratıcı dramayı planlama sürecinde de devam etmesi olası gözükmektedir.

Bunun nedenlerinden biri; önceki yıllarda eğitim fakültelerinde okulöncesi, sınıf ve sosyal bilgiler öğretmenliği programlarında zorunlu ders olarak okutulan yaratıcı dramanın, 2018 yılında öğretmenlik programlarında yapılan güncelleme (Yükseköğretim Kurulu, 2018) sonucunda sosyal bilgiler öğretmenliğinde zorunlu ders olmaktan çıkartılmasıdır. Buna ek olarak; yaratıcı dramanın zorunlu ders olarak okutulduğu programlardaki ders saatleri azaltılmış, dersin uygulama boyutu kaldırılmıştır. Oysa Yükseköğretim Kurulu (2018) tarafından "eğitimde drama" dersi için belirlenmiş kur tanımında; "yaratıcı drama ders planının hazırlanması ve uygulanması" biçiminde 
bir ifade bulunmaktadır. "Eğitimde drama" dersinin kur tanımında yer verilen "yaratıcı drama ders planının hazırlanması ve uygulanması" amacının, dersin öğretmenlik programlarındaki mevcut durumuyla gerçekleştirilemeyeceği ortadadır. Bu bağlamda, uygulama boyutu eksik bırakılmış, iki saatlik kuramsal bir derse dönüştürülmüş "eğitimde drama” dersinin etkili öğretimi olanaklı gözükmemektedir. 2018 y1lında öğretmenlik programlarında gerçekleştirilen değişikliklerin olumlu yönlerinden biri "eğitimde drama" dersine meslek bilgisi seçmeleri dersleri arasında yer verilmesidir. Böylece bütün öğretmen adayları bu dersi seçebileceklerdir. Ancak bu ders de iki saatlik kuramsal ders olarak tanımlanmıştır.

Üniversitelerdeki öğretmenlik programlarında yaratıcı drama derslerini veren öğretim elemanlarının, yaratıcı drama dersinin yeni öğretmenlik programlarındaki durumuna ilişkin görüşlerinin değerlendirildiği bir çalışmada (Metinnam, 2018) da yaratıcı drama dersinin yeni programlardaki ders saatiyle verilmesinin uygulama kısmının eksik kalmasına, yaratıcı drama yönteminin doğru biçimde uygulanamamasına neden olabileceği yönünde bulgulara ulaşılmıştır. $\mathrm{Bu}$ yüzden, yaratıcı dramanın ders saatlerinin düşürülerek uygulama boyutunun kaldırılması yaratıcı dramanın yöntem olarak kullanılmasına ilişkin sorunların çözüme ulaşacağı bir ortamdan çok sorunların daha da derinleşeceği bir öğretim sürecinin habercisi olabilir. Alanyazındaki çalışmalarda da öğretmen adaylarının yaratıcı dramayı planlayamadıklarını ve uygulayamadıklarını ifade ettikleri (Kuşdemir-Kayıran, 2018), kendilerini planlamada yetersiz gördükleri ( Özer, İlhan ve Taşkya, 2017) çalışmalara rastlanmaktadır.

$\mathrm{Bu}$ çalışma, öğretmen adaylarının planlama öz-yeterliklerini ortaya koymak gibi bir amaç gütmemektedir. Çalışmanın amacı, yalnızca öğretmen adaylarının yaratıcı drama planlama süreçlerinde yaşadıkları sorunları belirlemek ve bu sorunları öğretmen adaylarının gözünden aktarmaktır. Bu yüzden alanyazında çalışmayı destekleyecek benzer çalışmalara pek rastlanmamıştır. Sonuç olarak, öğretmen adayları yaratıcı drama planlama süreçlerinde çeşitli sorunlar yaşadıklarını ifade etmişlerdir. Bu sorunların çözümü için yeni öğretmenlik programlarında ders saati düşürülerek uygulama boyutu kaldırılan yaratıcı dramanın ders saatinin artırılarak uygulama boyutunun geri getirilmesi, öğretmen adaylarının kurmaca nitelikli sanat yapıtlarıyla (roman, öykü, sinema filmi, tiyatro vd.) daha çok buluşturularak kurmacaya ve kurguya dönük deneyimlerinin zenginleştirilmesi, eğitim fakültelerinde yaratıcı drama anabilim dalları açılarak öğretmenlik programlarında eğitim gören öğretmen adaylarına "yaratıcı drama öğretmenliği” nde yandal yapabilecekleri koşulların sağlanması önerilmektedir. 


\section{Kaynakça}

Adıgüzel, H. Ö. (2002). Eğitim bilimlerinde ve sanat eğitiminde yöntem, disiplin ve sanatsal boyutlarıyla yaratıcı drama. 11. Eğitim Bilimleri Kongresi. Yakın Doğu Üniversitesi: KKTC, 23-26 Ekim.

Adıgüzel, H. Ö. (2006). Yaratıı drama kavramı, bileşenleri ve aşamaları. Yaratıcı Drama Dergisi, 1(1), 17-29.

Adıgüzel, Ö. (2016). Bir ders ve yöntem olarak yaratıcı drama alanında yapılan çalışma ve gelişmeler. N. Aykaç (Ed.), 24. Uluslararası Eğitimde Yaratıcı Drama Kongresi "Ders Drama Yöntem Drama" kitabı içinde (s. 9-13). Muğla: Muğla Sitkı Koçman Üniversitesi.

Adıgüzel , Ö. (2018). Eğitimde yaratıcı drama. İstanbul: Yapı Kredi Yayınları.

Akdemir, H. ve Karakuş, M. (2016). Yaratıcı drama yönteminin akademik başarı üzerine etkisi: Bir meta-analiz çalışması. International Journal of Active Learning, 1(2), 55-67.

Akyel, Y. ve Çalışkan, N. (2013). Okul öncesi eğitim kurumlarında görev yapan öğretmenlerin drama yöntemi yeterliliklerinin değerlendirilmesi. Ahi Evran Üniversitesi Kırşehir Eğitim Fakültesi Dergisi, 14(3), 161173.

Batd, V. ve Batd, C. (2015). Effect of creative drama on academic achievement:A meta-analytic and thematic analysis. Educational Sciences: Theory and Practice, 15(6), 1459-1470.

Bowell, P. ve Heep, B. S. (2001). Planning process drama. London: David Fulton Publishers Ltd.

Cantürk-Günhan, B. (2016). Türkiye'de uygulanan drama temelli eğitimin matematik başarısına etkisi: Bir meta-analiz çalışması. International Online Journal of Educational Sciences, 8 (2), 145-162

Çelik, S. (2013). İlköğretim matematik derslerinde kullanılan alternatif öğretim yöntemlerinin akademik başarıya etkisi: bir meta analiz çalışması. Yayımlanmamış yüksek lisans tezi, Eskişehir Osmangazi Üniversitesi, Eskişehir.

Çelikkaya, T. ve Koç, İ. (2015). Öğretmenlerin sosyal bilgiler dersinde drama yöntemini uygulama yeterliliklerin belirlenmesi. Uluslararası Türk Eğitim Bilimleri Dergisi, 2015(4), 304-316.

Çetingöz, D. ve Cantürk-Günhan, B. (2011). Drama uygulamalarının okul öncesi eğitimi öğretmen adaylarının drama etkinlikleri planlama becerilerine yönelik görüşleri üzerindeki etkileri. Mersin Üniversitesi Ĕgitim Fakültesi Dergisi, 7(1), 89-99.

Çıkla, S. (2002). Romanda kurmaca ve gerçeklik. Hece Aylık Edebiyat Dergisi, 6(65/66/67), 111-129.

Fleming, M. (2003). Starting drama teaching. New York: David Fulton Publishers.

Kesici, A. E. (2014). Drama dersine ilişkin öğretmen görüşleri. Abant İzzet Baysal Üniversitesi Eğitim Fakültesi Dergisi, 14(2), 186-203.

Kuşdemir-Kayıran, B. (2018). Sınıf öğretmenliği adaylarının yaratıcı dramaya ilişkin algıları ve tutumları üzerine bir çalışma. Bursa Uludağ Üniversitesi Ĕgitim Fakültesi Dergisi, 31(2), 679-708.

Lee, B. K., Patall, E. A., Cawthon, S. W., \& Steingut, R. R. (2014). The effect of drama-based pedagogy on PreK-16 outcomes: a meta-analysis of research from 1985 to 2012. Review of Educational Research, 20(10), 1-47.

McCaslin, N. (2016). Sinıf içinde ve dışında yaratıcı drama (P. Özdemir Şimşek, Çev. Ed.). Ankara: Nobel Akademik Yayıncılık.

Merriam, S. B. (2002). Qualitative research in practice: Examples for discussion and analysis. San Francisco: Jossey-Bass.

Mesleki Yeterlilikler Kurumu (2018), 6. Seviye yaratıcı drama eğitmeni ulusal meslek standartları. Erişim adresi https://portal.myk.gov.tr/index.php?option=com_meslek_std_taslak\&view=taslak_revizyon\&tas$\mathrm{k}=$ indir\&id $=4 \&$ standart_id $=3792$

Metinnam, İ. (2018). Yeni öğretmen yetiştirme programlarında drama dersi. 13. Uluslararası Balkan Eğitim ve Bilim Kongresi. Trakya Üniversitesi: Türkiye, 6-8 Eylül 2018.

Özer, M. H. ve İlhan, E. ve Taşkaya, S. M. (2017). Sınıf öğretmenlerinin drama yöntemine ilişkin görüşlerinin incelenmesi. Uluslararası Çocuk Edebiyatı ve Eğitim Araştırmaları Dergisi, 1, 39-50. 
Şahin, A. (2017). Drama dersini alan ve almayan sınıf öğretmeni adaylarının drama tekniğiyle ilgili algılarının ve öz yeterliliklerinin karşılaştırılması. Bayburt Eğitim Fakültesi Dergisi, 12(23), 353-365.

Şahin, A. (2018). Sınıf ve Türkçe öğretmeni adaylarının drama yöntemini kullanmaya yönelik algılarının ve öz yeterlik düzeylerinin belirlenmesi. Trakya Üniversitesi Sosyal Bilimler Dergisi, 20 (1), 1-13.

Taylor, P. (2003). The drama classroom: Action, reflection, transformation. London and Newyork: RoutledgeFalmer.

Toraman, Ç. ve Ulubey, Ö. (2016). The effect of creative drama method on the attitude towards course: A meta-analysis study. Eğitim Bilimleri Araştırmaları Dergisi Uluslararası E-Dergi, 6(1), 87-115.

Toyle, N. ve Prendville, F. (2000). Drama and traditional story for the early years. Oxon: RoutledgeFalmer.

Ulubey, Ö. ve Toraman, Ç. (2015). Yaratıcı drama yönteminin akademik başarıya etkisi: Bir meta-analiz çalışmas1. Mustafa Kemal Üniversitesi Sosyal Bilimler Enstitüsü Dergisi, 12(32), 195-220.

Ulubey, Ö. (2018). The effect of creative drama as a method on skills: A meta-analysis study. Journal of Education and Training Studies, 6(4), 63-78.

Yıldırım, A. ve Şimşek, H. (2013). Sosyal bilimlerde nitel araştırma yöntemleri. Ankara: Seçkin Yayıncılık.

Yükseköğretim Kurulu (2018). Yeni öğretmen yetiştirme lisans programları. Erişim adresi https://www.yok. gov.tr/kurumsal/idari-birimler/egitim-ogretim-dairesi/yeni-ogretmen-yetistirme-lisans-programlari 


\section{Ekler}

Ek-1: "Yaratıcı Dramayı Planlama ve Yapılandırmada Adıgüzel Yaklaşımı" Örnek Yaratıcı Drama Planı Şablonu

\section{Ders:}

Konu (Tema):

Kazanımlar:

Süre:

Sınıf (Çalışılacak Grup):

Araç-Gereçler:

Yöntem ve Teknikler:

Süreç:

\section{Hazırlık-Isınma Çalışmaları}

1. Etkinlik

2. Etkinlik

II. Canlandirma

3. Etkinlik

4. Etkinlik

III. Değerlendirme-Tartışma

5. Etkinlik 
